\title{
Removal of Tetracycline by Hydrous Ferric Oxide: Adsorption Kinetics, Isotherms, and Mechanism
}

\author{
Ji Zang, Tiantian Wu, Huihui Song, Nan Zhou, Shisuo Fan, Zhengxin Xie and Jun Tang * \\ College of Resource and Environment, Anhui Agricultural University, Key Laboratory of Agri-Food Safety of \\ Anhui Province, Hefei 230036, China; 18895688872@163.com (J.Z.); wu18365280208@163.com (T.W.); \\ songhuihui188@163.com (H.S.); 18726172019@163.com (N.Z.); fanshisuo@126.com (S.F.); \\ xiezx@ahau.edu.cn (Z.X.) \\ * Correspondence: tangjun@ahau.edu.cn; Tel.: +86-551-6578-6790
}

Received: 1 October 2019; Accepted: 14 November 2019; Published: 19 November 2019

\begin{abstract}
The removal of tetracycline (TC) from solution is an important environmental issue. Here we prepared an adsorbent hydrous ferric oxide (HFO) by adjusting a $\mathrm{FeCl}_{3} \cdot 6 \mathrm{H}_{2} \mathrm{O}$ solution to neutral $\mathrm{pH}$. HFO was characterized by a surface area analyzer, X-ray diffraction (XRD), Fourier transform infrared spectroscopy (FTIR), and X-ray photoelectron spectroscopy (XPS), and was used to remove $\mathrm{TC}$ from solution. The influence of $\mathrm{pH}$, solid-to-liquid ratio, ionic type, and strength on TC removal was investigated. Adsorption kinetics and isotherms were also determined. HFO after adsorption of TC was analyzed by FTIR and XPS to investigate the adsorption mechanism. The results showed that the adsorption of TC increased from $88.3 \%$ to $95 \%$ with increasing $\mathrm{pH}(3.0-7.0)$ and then decreased. $\mathrm{K}^{+}$ions had little effect on TC adsorption by HFO. However, $\mathrm{Ca}^{2+}$ and $\mathrm{Mg}^{2+}$ reduced the adsorption of TC on HFO. When the concentrations of $\mathrm{Ca}^{2+}$ and $\mathrm{Mg}^{2+}$ were increased, the inhibitory effect was more obvious. Pseudo-second-order kinetics and the Langmuir model fitted the adsorption process well. The maximum adsorption capacity of TC on HFO reached $99.49 \mathrm{mg} \cdot \mathrm{g}^{-1}$. The adsorption process was spontaneous, endothermic, and increasingly disordered. Combination analysis with FTIR and XPS showed that the mechanism between TC and HFO involved electrostatic interactions, hydrogen interactions, and complexation. Therefore, the environmental behavior of TC could be affected by HFO.
\end{abstract}

Keywords: hydrous ferric oxide; tetracycline; influencing factors; adsorption behavior; mechanism

\section{Introduction}

Antibiotics have received increasing attention due to their various adverse effects in the aquatic environment. Tetracyclines (TCs) represent one of the most widely used antibiotic agents both in veterinary science and aquaculture, with an annual usage of more than 6950 tons in China [1]. TCs in the environment presented at very low concentrations $(\mu \mathrm{g} / \mathrm{L}$ to $\mathrm{ng} / \mathrm{L}$ ) in treated waters and higher levels $(100-500 \mathrm{mg} / \mathrm{L})$ were detected in effluents from hospital and pharmaceutical manufacturing wastewaters [2-4]. TCs can persist in the environment for a long time, and they have high aqueous solubility [5]. Long-term exposure to TCs can cause pathogenic microorganisms to develop antibiotic resistance [6]. Furthermore, resistant genes can spread and evolve in the environment, posing potential threats to ecological environments and human health. Therefore, the removal of antibiotics from the aqueous environment is crucial.

Generally, the techniques used for antibiotic removal from aqueous solution involve adsorption [7-9], advanced oxidation [10,11], and biological methods [12]. Due to the advantages of low cost, simple operation, high efficiency, and recycling of the adsorbent, adsorption has become one of the most effective methods for TC removal [13]. Various adsorbent materials have been used for the removal of 
TCs from aqueous solution, including graphene oxide [14], graphene oxide functionalized magnetic particles [14], chitosan [15], ferric activated sludge-based adsorbent [16], activated carbon [17], and others.

Hydrous ferric oxide (HFO) is a widespread iron oxide present in natural water and soil [18]. HFO is an excellent adsorbent and can remove many pollutants, such as ammonium, phosphate, and fluoride, and can affect the transfer and transformation of pollutants [19-21]. The active sites on HFO can bind pollutants via surface complexation or ligand exchange. Pollutant removal from wastewater by HFO or modified HFO has been reported, including phosphorus [20,22], fluoride [23], antimony [24], and heavy metal ions [25], etc. Antibiotic removal by HFO has also been reported, including sulfadimethoxine [8]. $\mathrm{Gu}$ et al. [26] reported that HFO can influence the mobility and environmental reactivity of TC in complex environmental matrices. However, the presence of competing cations, the influence of temperature, and potential mechanism should be studied further. In addition, HFO is the most important component of iron plaque (up to $81 \%-100 \%$ ) around the roots of hydrophilous plants [27] and plays a key role in the bioaccumulation of various contaminants in wetland plants [28]. Given the effect on uptake and translocation of norfloxacin in rice by iron plaques [29], the adsorption behavior and mechanism of antibiotics by HFO require further investigation to better understand the environmental behavior of antibiotics.

In this study, $\mathrm{HFO}$ was synthesized using $\mathrm{FeCl}_{3} \cdot 6 \mathrm{H}_{2} \mathrm{O}$ and was characterized by XRD, FTIR, and XPS. The effect of HFO dosage, $\mathrm{pH}$, ionic types and strength on TC removal by HFO was investigated. The adsorption kinetics and isotherms were also studied. In addition, the adsorption mechanism was determined to better understand the environmental behavior of TC influenced by HFO.

\section{Materials and Methods}

\subsection{Reagents}

All the chemicals used in this study were of analytical grade. Ferric chloride hexahydrate $\left(\mathrm{FeCl}_{3} \cdot 6 \mathrm{H}_{2} \mathrm{O}\right)$ and $\mathrm{MgCl}_{2} \cdot 6 \mathrm{H}_{2} \mathrm{O}$ were bought from Sinopharm Chemical Reagent Co., Ltd (Shanghai, China). Sodium hydroxide $(\mathrm{NaOH})$, hydrogen chloride $(\mathrm{HCl})$, potassium chloride $(\mathrm{KCl})$, and calcium chloride $\left(\mathrm{CaCl}_{2} \cdot 2 \mathrm{H}_{2} \mathrm{O}\right)$ were obtained from Xilong Scientific Co., Ltd. (Guangzhou, China). High-performance liquid chromatography grade methyl alcohol and acetonitrile were purchased from Tedia (Fairfield, $\mathrm{OH}$, USA). Tetracycline hydrochloride (purity 98\%) was purchased from Shanghai Yuanye Reagent Company (Shanghai, China). Deionized water was obtained from a Milli-Q Plus ultrapure water system (Billerica, MA, USA).

\subsection{Synthesis of $\mathrm{HFO}$}

The synthesis of $\mathrm{HFO}$ was based on the study by Gu [26], and the steps were as follows: $\mathrm{FeCl}_{3} \cdot 6 \mathrm{H}_{2} \mathrm{O}$ $\left(0.8 \mathrm{~mol} \cdot \mathrm{L}^{-1}\right)$ was dissolved in deionized water under vigorous magnetic stirring, and then $\mathrm{NaOH}$ solution was slowly added into the $\mathrm{FeCl}_{3} \cdot 6 \mathrm{H}_{2} \mathrm{O}$ solution until the $\mathrm{pH}$ value was $7-8$. The formed suspension was continuously stirred for $1 \mathrm{~h}$, and aged at room temperature for $24 \mathrm{~h}$. The precipitated HFO particles were collected by centrifugation and then washed three times with ultrapure Milli-Q water to remove residual ions. Finally, the HFO was freeze-dried, ground in an agate mortar and passed through a 200-mesh sieve. The obtained HFO was collected and stored in a brown glass bottle until used.

\subsection{Adsorption Experiments}

A standard stock solution of $1000 \mathrm{mg} \cdot \mathrm{L}^{-1} \mathrm{TC}$ was prepared and stored in the refrigerator at $4{ }^{\circ} \mathrm{C}$. All other experimental concentrations of TC solutions were obtained by diluting the stock solution. Forty milliliters of the desired TC solution was placed in a $100 \mathrm{~mL}$ conical flask and oscillated at $298 \mathrm{~K}$ and a speed of $150 \mathrm{rpm}$ for batch adsorption experiments. Samples were taken at a given time, centrifuged at 10,000 rpm for $10 \mathrm{~min}$, and then collected for further analysis. 
The influence of adsorbent dosage, $\mathrm{pH}$ value, and ionic strength on TC adsorption were investigated. Fifty milligrams of HFO was added to $50 \mathrm{~mL}$ of TC solution $\left(40 \mathrm{mg} \cdot \mathrm{L}^{-1}\right)$ in a conical flask and the initial $\mathrm{pH}$ value of the solution was adjusted from 3.0 to 11.0 by adding $0.1 \mathrm{~mol} \cdot \mathrm{L}^{-1} \mathrm{HCl}$ or $0.1 \mathrm{~mol} \cdot \mathrm{L}^{-1} \mathrm{NaOH}$ using a PHS-3C $\mathrm{pH}$ meter (Shanghai Electronics Science Instrument Co., Ltd., Shanghai, China). $\mathrm{KCl}, \mathrm{CaCl}_{2}$, and $\mathrm{MgCl}_{2}$ at different concentrations $\left(0.02,0.10\right.$, and $\left.0.50 \mathrm{~mol} \cdot \mathrm{L}^{-1}\right)$ were selected to analyze the impact of ionic type and strength on adsorption. The experimental time for the effect of $\mathrm{pH}$ and ionic types was $7 \mathrm{~h}$. The removal rate is listed in Equation (1).

$$
\mathrm{R}=\left(\mathrm{C}_{0}-\mathrm{C}_{\mathrm{e}}\right) / \mathrm{C}_{0} \times 100 \%,
$$

where $\mathrm{R}$ is the removal rate, $\% . \mathrm{C}_{0}$ and $\mathrm{C}_{\mathrm{e}}$ are the initial and the equilibrium concentration of TC in the solution phase, respectively, $\mathrm{mg} \cdot \mathrm{L}^{-1}$.

To measure the adsorption kinetics, $0.1 \mathrm{~g}$ of $\mathrm{HFO}$ was added to the TC solution $\left(40 \mathrm{mg} \cdot \mathrm{L}^{-1}, 40 \mathrm{~mL}\right)$, and the sampling times were set at intervals of $10 \mathrm{~min}$ up to $1260 \mathrm{~min}$. The amount of TC adsorbed at $t$ time, $\mathrm{q}_{\mathrm{t}}\left(\mathrm{mg} \cdot \mathrm{L}^{-1}\right)$, was determined according to Equation (2).

$$
\mathrm{q}_{\mathrm{t}}=\left(\mathrm{C}_{0}-\mathrm{C}_{\mathrm{e}}\right) \mathrm{V} / \mathrm{m},
$$

where $\mathrm{q}_{\mathrm{t}}$ is the amount adsorbed at equilibrium time, $\mathrm{mg}^{-\mathrm{g}^{-1}} ; \mathrm{V}$ is the volume of solution, $\mathrm{L} ; \mathrm{m}$ is the mass of adsorbent, $\mathrm{g}$.

To study the adsorption isotherms, different concentrations of TC $\left(10,20,30,40,50,60,70 \mathrm{mg} \cdot \mathrm{L}^{-1}\right)$ were placed in a $100 \mathrm{~mL}$ conical flask with $0.1 \mathrm{~g} \mathrm{HFO}$ at 298, 308, and $318 \mathrm{~K}$, respectively, and the agitation time was set at $420 \mathrm{~min}$ according to the results of the adsorption kinetics. The amount of TC adsorbed, $\mathrm{q}_{\mathrm{e}}\left(\mathrm{mg} \cdot \mathrm{L}^{-1}\right)$, was calculated by Equation (3).

$$
\mathrm{q}_{\mathrm{e}}=\left(\mathrm{C}_{0}-\mathrm{C}_{\mathrm{e}}\right) \times \mathrm{V} / \mathrm{m} \text {. }
$$

Pseudo-first-order and pseudo-second-order models were used to fit the adsorption kinetic process, and the Langmuir and Freundlich models were applied to simulate the adsorption isotherm data.

\subsection{Measurement of TC}

TC was analyzed by ultra-performance liquid chromatography (Waters, Milford, MA, USA) with the column oven temperature maintained at $40{ }^{\circ} \mathrm{C}$, using a BEH $\mathrm{C}_{18}$ reversed-phase column $(100 \mathrm{~mm} \times 2.1 \mathrm{~mm}$ i.d., $1.7 \mu \mathrm{m})$. The mobile phase consisted of water containing $1 \%$ o formic acid (A) and acetonitrile (B). The gradient was set as follows: $95.0 \% \mathrm{~A}(0 \mathrm{~min}), 5.0 \% \mathrm{~A}(2.5 \mathrm{~min}), 95.0 \% \mathrm{~A}$ (3.51 $\mathrm{min}), 95.0 \% \mathrm{~A}(5 \mathrm{~min})$ and the flow rate was $0.30 \mathrm{~mL} \cdot \mathrm{min}^{-1}$. The injection volume was $10 \mu \mathrm{L}$, and the detection wavelength was $254 \mathrm{~nm}$. Each experiment was repeated three times, and the average values are presented.

\subsection{Characterizations}

Determination of pHpzc (point of zero charge): $40 \mathrm{~mL}$ of pure water was added to a $50 \mathrm{~mL}$ centrifugal tube. The initial $\mathrm{pH}\left(\mathrm{pHi}\right.$ ) of the solution was adjusted to $2.0-10.0$ using $0.1 \mathrm{~mol} \cdot \mathrm{L}^{-1} \mathrm{HCl}$ or $0.1 \mathrm{~mol} \cdot \mathrm{L}^{-1} \mathrm{NaOH}$. Then, $0.04 \mathrm{~g} \mathrm{HFO}$ was added to each centrifugal cube. After stirring in a shaker for $24 \mathrm{~h}$, the suspension was centrifuged, and the $\mathrm{pH}$ of the supernatant was measured ( $\mathrm{pHf}$ ). The value of pHpzc was obtained when the value of $\mathrm{pHi}$ was equal to $\mathrm{pHf}$.

The minerals in $\mathrm{HFO}$ were detected by an $\mathrm{X}$-ray diffractometer with $\mathrm{Cu}$ radiation (PANalytical $X^{\prime}$ Pert PRO X'Celerator). The functional groups in the sample were determined by Fourier transform infrared spectroscopy (FTIR Nicolette is 50, Thermo Fisher Scientific, Waltham, MA, USA) using the KBr pellet technique with $4 \mathrm{~cm}^{-1}$ resolution measuring the absorbance from 4000 to $400 \mathrm{~cm}^{-1}$. The sample for FTIR analysis was crushed and was passed through a 200 mesh sieve. The valence elements in HFO and HFO-adsorbed TC were analyzed via X-ray photoelectron spectroscopy (XPS, Thermo 
ESCALAB 250, Thermo-VG Scientific, Waltham, MA, USA). XPS was used to determine the valence state of the chemical elements by analyzing the energy distribution of photoelectrons. The specific surface area, pore volume, and pore size of the HFO were determined using a surface area and porosity analyzer (Micromeritics, Tristar II 3020, Atlanta, GA, USA) at $77 \mathrm{~K}$ under $\mathrm{N}_{2}$ atmosphere. The particle size of HFO was measured using a BT-9300H laser particle analyzer (Dandong Baite Instrument Co., Ltd., Liaoning, China).

\subsection{Adsorption Models}

Pseudo-first-order and pseudo-second-order models were used to fit the adsorption kinetic process. Pseudo-first-order kinetic model [30]:

$$
\mathrm{q}_{\mathrm{t}}=\mathrm{q}_{\mathrm{e}}\left(1-\exp \left(-\mathrm{k}_{1} \mathrm{t}\right)\right)
$$

Pseudo-second-order kinetic model [31]:

$$
\mathrm{q}_{\mathrm{t}}=\left(\mathrm{k}_{2} \mathrm{qe}^{2} \mathrm{t}\right) /\left(1+\mathrm{k}_{2} \mathrm{q}_{\mathrm{e}} \mathrm{t}\right),
$$

where $\mathrm{q}_{\mathrm{t}}\left(\mathrm{mg}^{-\mathrm{g}^{-1}}\right)$ and $\mathrm{q}_{\mathrm{e}}\left(\mathrm{mg} \cdot \mathrm{g}^{-1}\right)$ are the amounts of adsorbed at time $\mathrm{t}$ and equilibrium time, respectively. The $\mathrm{k}_{1}\left(\mathrm{~min}^{-1}\right)$ and $\mathrm{k}_{2}\left(\mathrm{~g} \cdot\left(\mathrm{mg} \cdot \mathrm{min}^{-1}\right)\right)$ are the adsorption rate constant of the pseudo-first-order and pseudo-second-order model, respectively.

The Langmuir and Freundlich models were applied to fit the adsorption isotherm process.

Langmuir [32]:

$$
\mathrm{q}_{\mathrm{e}}=\left(\mathrm{q}_{\mathrm{m}} \cdot \mathrm{K}_{\mathrm{L}} \cdot \mathrm{c}_{\mathrm{e}}\right) /\left(1+\mathrm{K}_{\mathrm{L}} \cdot \mathrm{C}_{\mathrm{e}}\right)
$$

Freundlich [33]:

$$
\mathrm{q}_{\mathrm{e}}=K_{f} \cdot \mathrm{C}_{\mathrm{e}}^{1 / \mathrm{n}}
$$

where $\mathrm{q}_{\mathrm{e}}\left(\mathrm{mg} \cdot \mathrm{g}^{-1}\right)$ is the equilibrium adsorption capacity; $\mathrm{q}_{\mathrm{m}}(\mathrm{mg})$ is the maximum adsorption capacity.

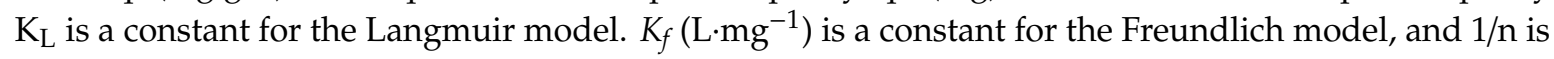
the adsorption affinity constant.

To better understand the effect of temperature on the adsorption of TC on the HFO composite, the thermodynamic parameters of the adsorption process, such as a change in standard free energy $(\Delta \mathrm{G})$, enthalpy $(\Delta \mathrm{H})$, and entropy $(\Delta \mathrm{S})$, were calculated using Equations (9)-(11) [34,35].

$$
\begin{gathered}
\mathrm{K}_{\mathrm{d}}=\frac{\mathrm{q}_{\mathrm{e}}}{\mathrm{C}_{\mathrm{e}}}, \\
\Delta \mathrm{G}=-\mathrm{R} \ln \left(\mathrm{K}_{\mathrm{d}}\right), \\
\ln \mathrm{K}_{\mathrm{d}}=\frac{\Delta \mathrm{S}}{\mathrm{R}}-\frac{\Delta \mathrm{H}}{\mathrm{R}} \frac{1}{\mathrm{~T}},
\end{gathered}
$$

where $K_{d}$ is the apparent equilibrium constant; $R$ is the ideal gas constant $\left(8.314 \mathrm{~J} \mathrm{~mol}^{-1} \mathrm{~K}^{-1}\right)$, and $\mathrm{T}$ is Kelvin temperature (K).

According to the method suggested by Khan and Singh [34], the sorption distribution coefficient $K_{d}$ for the sorption reaction was determined from the slope of the plot $\ln \left(\mathrm{q}_{\mathrm{e}} / \mathrm{C}_{\mathrm{e}}\right)$ against $\mathrm{C}_{\mathrm{e}}$ at various temperatures and extrapolating to zero $\mathrm{C}_{\mathrm{e}}$. The values of $\Delta \mathrm{H}$ and $\Delta \mathrm{S}$ can be obtained from the slope and intercept of a plot of $\ln \left(\mathrm{K}_{\mathrm{d}}\right)$ against $1 / \mathrm{T}$.

\section{Results and Discussion}

\subsection{Characterization of HFO}

The specific surface area, pore volume, and pore size of the HFO were $226.796 \mathrm{~m}^{2} \cdot \mathrm{g}^{-1}, 0.167 \mathrm{~cm}^{3} \cdot \mathrm{g}^{-1}$, and $3.495 \mathrm{~nm}$, respectively. The D10, D50, and D90 of HFO particles were 5.279, 27.70, and $65.89 \mu \mathrm{m}$, 
respectively. Thus, the pore structure of HFO was developed, and the particles of HFO was relatively large, which was beneficial for TC adsorption.

The XRD of HFO is presented in Figure 1a. The XRD pattern indicated that HFO had poor crystallinity. HFO showed two broad peaks at $36.4^{\circ}$ and $64.2^{\circ}$, which matched with the poorly ordered ferrihydrite mineral. Hofmann et al. [36] found that these peaks were similar to ferrihydrite.
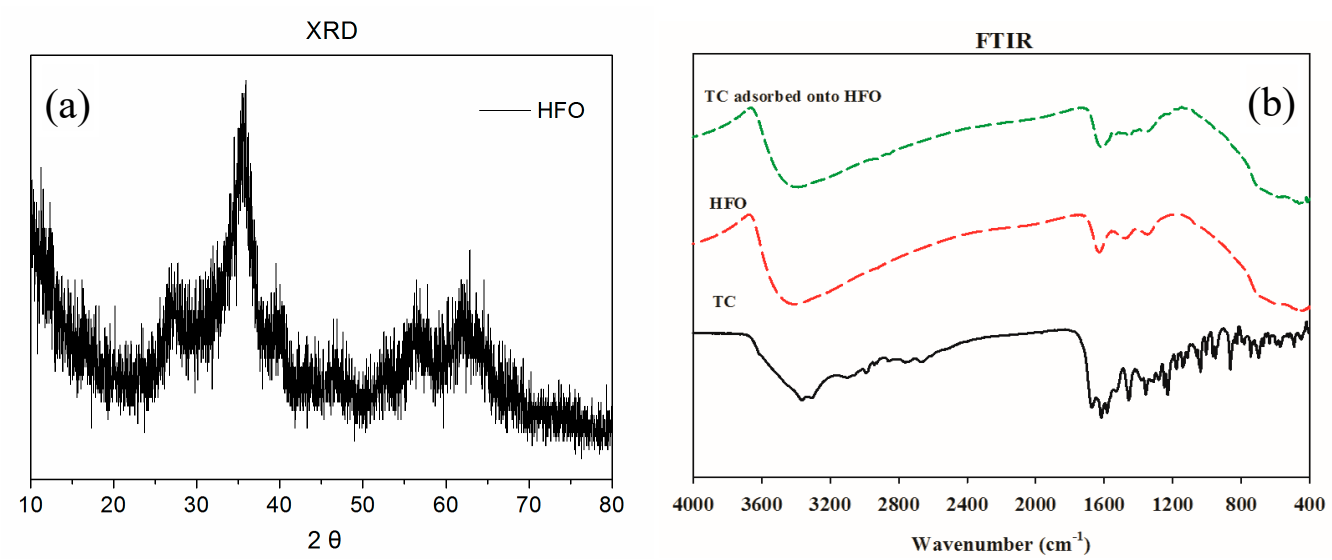

Figure 1. XRD (a) and FTIR (b) spectra of hydrous ferric oxide (HFO).

The FTIR spectra of HFO, TC, and TC adsorbed onto HFO are displayed in Figure 1b, and specific functional groups are listed in Table 1. The main functional groups of $\mathrm{HFO}$ included $-\mathrm{OH}\left(3405 \mathrm{~cm}^{-1}\right.$, $\left.1629 \mathrm{~cm}^{-1}\right), \mathrm{CH}_{3} / \mathrm{COO}\left(1477 \mathrm{~cm}^{-1}, 1348 \mathrm{~cm}^{-1}\right)$, and Fe-O $\left(444 \mathrm{~cm}^{-1}\right)$. After TC was adsorbed on HFO, some new peaks appeared, involving amino groups $\left(1535 \mathrm{~cm}^{-1}\right)$ and $\mathrm{C}-\mathrm{OH}$ stretching $\left(1224 \mathrm{~cm}^{-1}\right)$, suggesting that TC had been adsorbed on the surface of HFO.

Table 1. Functional groups of hydrous ferric oxide (HFO) and HFO + tetracycline (TC).

\begin{tabular}{cccc}
\hline & HFO & \multicolumn{2}{c}{ HFO + TC } \\
\hline Wavenumber $\left(\mathbf{c m}^{\mathbf{- 1}}\right)$ & Assignment & Wavenumber $\left.\mathbf{( c m}^{\mathbf{- 1}}\right)$ & Assignment \\
\hline 3405 & $\begin{array}{c}\text { stretching } \\
\text { vibration mode of lattice water }\end{array}$ & 3387 & $\begin{array}{c}\text { stretching } \\
\text { vibration mode of lattice water }\end{array}$ \\
\hline 1629 & $-\mathrm{OH}$ & 1618 & carbonyl groups \\
\hline 1477 & & 1535 & amino groups \\
\hline 1343 & $\mathrm{CH}_{3} / \mathrm{COO}$ & 1458 & $\mathrm{CH}_{3} / \mathrm{COO}$ \\
\hline & $\mathrm{CH}_{3} / \mathrm{COO}$ & 1383 & $\mathrm{CH}_{3} / \mathrm{COO}$ \\
\hline 444 & & 1224 & $\mathrm{C}-\mathrm{OH}$ stretching \\
& & 436 & Fo and OH groups \\
\hline
\end{tabular}

In addition, following TC adsorption, the peaks at $1629 \mathrm{~cm}^{-1}, 1477 \mathrm{~cm}^{-1}$, and $444 \mathrm{~cm}^{-1}$ shifted to $1617 \mathrm{~cm}^{-1}, 1458 \mathrm{~cm}^{-1}$, and $436 \mathrm{~cm}^{-1}$, respectively, indicating that $\mathrm{Fe}-\mathrm{O}, \mathrm{CH}_{3} / \mathrm{COO}$ and $-\mathrm{OH}$ in $\mathrm{HFO}$ participated in the removal of TC in solution. The main mechanism involved electrostatic interactions and complexation. Mudunkotuwa et al. [37] found that the ATR-FTIR spectra of $\alpha-\mathrm{Fe}_{2} \mathrm{O}_{3}$-adsorbed humic acid showed two new bands at 1348 and $1470 \mathrm{~cm}^{-1}$ during the initial time points, which corresponded to carboxylate groups strongly adsorbed to the surface iron atoms.

The XPS spectra of HFO and HFO-adsorbed TC are presented in Figure 2. The XPS-peak-differentiating analysis of $\mathrm{O} 1 \mathrm{~s}$ is shown in Figure 2a. The $\mathrm{O} 1 \mathrm{~s}$ XPS spectrum of TC can be separated into three peaks at 531.30, 532.45, and $533.24 \mathrm{eV}$, corresponding to $\mathrm{C}=\mathrm{O},-\mathrm{OH}$, and $\mathrm{C}-\mathrm{O}-\mathrm{C}$, respectively [13]. The $\mathrm{O} 1 \mathrm{~s}$ XPS spectrum of $\mathrm{HFO}$ can be separated into three peaks at $529.75,531.20$, and $531.58 \mathrm{eV}$, corresponding to $\mathrm{Fe}-\mathrm{O}, \mathrm{Fe}-\mathrm{OH}$, and $\mathrm{C}=\mathrm{O} /-\mathrm{OH}$, respectively [8]. Following TC adsorption, the $\mathrm{O} 1 \mathrm{~s}$ can be separated 
into three peaks at 529.84, 531.23, and 532.07 eV, which were ascribed to Fe-O, Fe-OH, and C=O/-OH, respectively. Therefore, the peak position and peak area of oxygen-containing groups in $\mathrm{HFO}$ obviously changed after TC adsorption. Thus, Fe-O, Fe-OH, and $\mathrm{C}=\mathrm{O} /-\mathrm{OH}$ participated in the adsorption of $\mathrm{TC}$, which mainly involved electrostatic interactions and surface complexation.
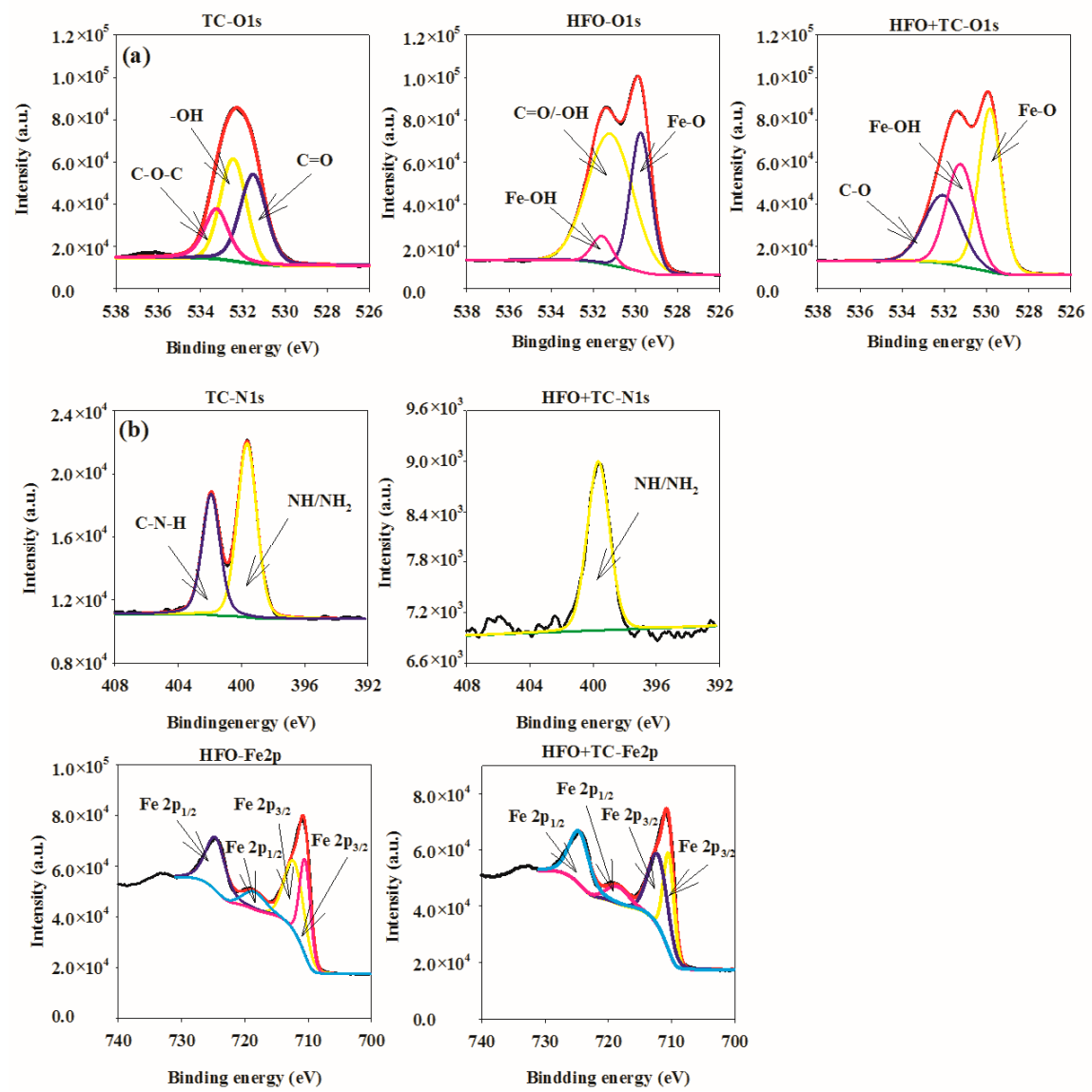

Figure 2. XPS spectral of HFO and HFO adsorbed tetracycline (TC).

The XPS-peak-differentiating analysis of $\mathrm{N} 1 \mathrm{~s}$ is displayed in Figure $2 \mathrm{~b}$. The $\mathrm{N} 1 \mathrm{~s}$ XPS spectrum of TC can be separated into two peaks at 399.65 and $401.92 \mathrm{eV}$, corresponding to NH/NH 2 and C-N-H, respectively [38]. Following TC adsorption, the N 1s was separated into one peak at $399.67 \mathrm{eV}$, which was ascribed to $\mathrm{NH} / \mathrm{NH}_{2}$. Therefore, the peak position and peak area of nitrogen-containing groups in HFO obviously changed after TC adsorption. Thus, nitrogen-containing groups participated in the adsorption of TC, which mainly involved electrostatic and hydrogen interactions.

The XPS-peak-differentiating analysis of Fe 2p is presented in Figure 2c. The Fe 2p XPS spectrum of $\mathrm{HFO}$ was separated into four peaks at 710.50, 712.23, 718.51, and 724.63 eV, corresponding to Fe 2 $\mathrm{p}_{3 / 2}$, Fe $2 p_{3 / 2}, F e p_{1 / 2}$, and Fe $2 p_{1 / 2}$, respectively. The Fe species in $\mathrm{HFO}$ refers to $\mathrm{Fe}_{2} \mathrm{O}_{3}, \mathrm{FeO}, \mathrm{FeOOH}$, which was consistent with the analysis of XRD. Following TC adsorption, the Fe $2 p$ spectrum was separated into four peaks at 710.44, 712.16, 718.50, and $724.58 \mathrm{eV}$, which were ascribed to Fe $2 \mathrm{p}_{3 / 2}, \mathrm{Fe} 2 \mathrm{p}_{3 / 2}$, Fe $2 p_{1 / 2}$, and Fe $2 p_{1 / 2}$, respectively. Therefore, the peak position and peak area of iron-containing groups in HFO obviously changed after TC adsorption. The iron-containing groups participated in the adsorption of TC, which mainly involved complexation.

As shown in Figure 3, the pHpzc value of HFO was 7.87. When the $\mathrm{pH}$ of the solution was lower than 7.87 , the surface of HFO had a positive charge. The surface of HFO had a negative charge when the $\mathrm{pH}$ of the solution was greater than 7.87. Okazaki et al. [39] found that the isoelectric point of HFO was 7.5. Kosmulski et al. [40] found that the isoelectric point of HFO was 7.2. 


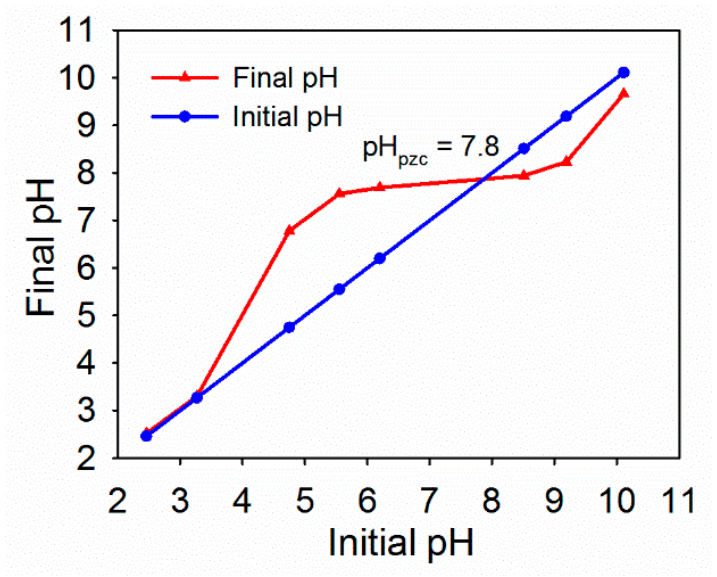

Figure 3. Point of zero charge (pHpzc) of HFO.

\subsection{Effect of HFO Dosage, $p H$, Ionic Types and Strength}

The effect of HFO dosage on TC removal is shown in Figure 4a. When the dosage of HFO was increased, the removal rate of TC quickly increased and then tended to stabilize. When the HFO dosage increased from 0.5 to $1.0 \mathrm{~g} \cdot \mathrm{L}^{-1}$, the removal rate of TC increased from $67.17 \%$ to $95.08 \%$. When the HFO dosage was larger than $1.0 \mathrm{~g} \cdot \mathrm{L}^{-1}$, the removal rate tended to stabilize, and the adsorption capacity reached $38.18 \mathrm{mg} \cdot \mathrm{g}^{-1}$. Thus, the optimum HFO dosage was chosen as $1.0 \mathrm{~g} \cdot \mathrm{L}^{-1}$.
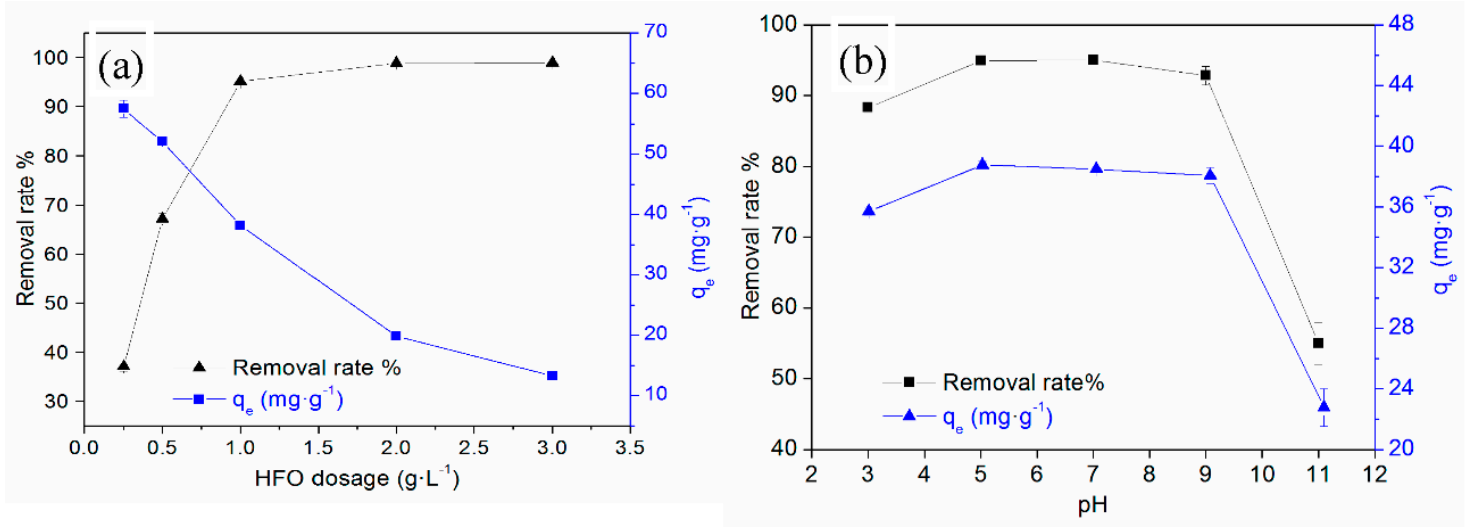

Figure 4. Effect of HFO dosage (a) and $\mathrm{pH}(\mathbf{b})$ on TC removal.

Solution $\mathrm{pH}$ was a key factor in affecting TC adsorption. Solution $\mathrm{pH}$ can affect the surface charge and ionization degree of HFO, the form, and the ionization degree of TC, consequently influencing the adsorption of TC on HFO. Tetracycline (symbolized as $\mathrm{H}_{2} \mathrm{TC}$ ) is an amphoteric molecule with multiple ionizable functional groups and may exist as a cations $\left(\mathrm{H}_{3} \mathrm{TC}^{+}, \mathrm{pH}<3.3\right)$, zwitterions $\left(\mathrm{H}_{2} \mathrm{TC}^{0}\right.$, $3.3<\mathrm{pH}<7.7)$, or negatively charged ions $\left(\mathrm{HTC}^{-}, 7.7<\mathrm{pH}<9.7 ; \mathrm{TC}_{2}^{-}, \mathrm{pH}>9.7\right)$ at different $\mathrm{pH}$ values [41]. The effect of $\mathrm{pH}$ on TC removal by HFO is shown in Figure $4 \mathrm{~b}$. The adsorption of TC on HFO increased from $88.3 \%$ to $95 \%$ with increasing $\mathrm{pH}(3-7)$ and then decreased. When the solution $\mathrm{pH}$ was 3.0, the removal rate was greater than $90 \%$, despite the presence of electrostatic repulsion, indicating other adsorption mechanisms also played a role. The removal rate of TC increased in the $\mathrm{pH}$ range of 3.0 to 5.0, due to the weakening of electrostatic repulsion. The removal rate slightly decreased at $\mathrm{pH}$ 5.0-9.0, although electrostatic repulsion was present, and it had little effect, suggesting other mechanisms played larger roles. However, the removal rate of TC significantly decreased when the $\mathrm{pH}$ value was greater than 9.0, indicating that electrostatic repulsion between TC and HFO dominated. When TC was removed by other adsorbents, such as iron hydrous oxides [26], iron-montmorillonite [42], montmorillonite [43], porous synthetic resins [44], and carbon nanotubes [45], it was found that at 
increased $\mathrm{pH}, \mathrm{TC}$ removal first increased and then decreased, which was attributed to complexation interactions, electrostatic interactions, ion exchange, cation $-\pi$ bonding, and $\pi-\pi$ EDA interactions.

Wastewater may contain high concentrations of salt ions, and the salt in water may affect the adsorption of TC by HFO. In this study, the effects of $\mathrm{K}^{+}, \mathrm{Ca}^{2+}$, and $\mathrm{Mg}^{2+}$ at different concentrations on TC adsorption by HFO were investigated, and the results are shown in Figure 5 . It can be seen that $\mathrm{K}^{+}$has little influence on TC removal by HFO. However, $\mathrm{Ca}^{2+}$ and $\mathrm{Mg}^{2+}$ had an obvious influence on TC removal. As the concentration of $\mathrm{Ca}^{2+}$ and $\mathrm{Mg}^{2+}$ increased, the removal rates of TC significantly decreased. When the concentration of $\mathrm{K}^{+}$increased from 0 to $0.5 \mathrm{~mol} \cdot \mathrm{L}^{-1}$, the removal rate of TC was almost unchanged. However, when the concentration increased from 0 to $0.5 \mathrm{~mol} \cdot \mathrm{L}^{-1}$, the removal rate of TC decreased from $96.50 \%$ to $17.18 \%$ for $\mathrm{Ca}^{2+}$ and from $96.50 \%$ to $27.13 \%$ for $\mathrm{Mg}^{2+}$, respectively. Thus, $\mathrm{Ca}^{2+}$ and $\mathrm{Mg}^{2+}$ in the solution reduced the removal of TC by HFO.

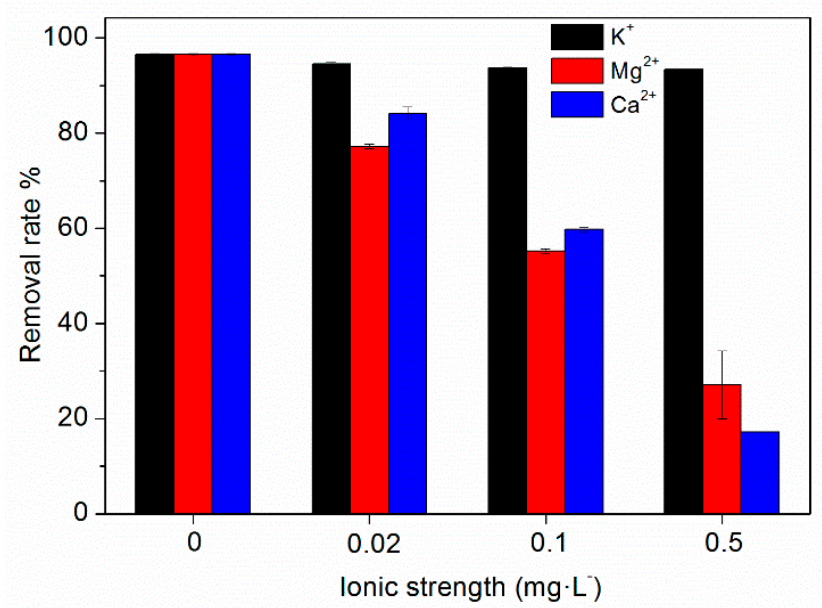

Figure 5. Effect of ionic types and strength on TC removal by HFO.

$\mathrm{Ca}^{2+}$ and $\mathrm{Mg}^{2+}$ may affect TC removal by competing with TC for adsorption sites on HFO; thus influencing complexation interactions, especially outer-sphere complexation, affecting the ion exchange mechanism, weakening the electrostatic interaction, and $\mathrm{Ca}^{2+}$ and $\mathrm{Mg}^{2+}$ could form a complex with TC, further affecting the adsorption of TC on HFO. Parolo et al. [46] reported that in the absence of $\mathrm{Ca}^{2+}$, TC adsorption was high at low $\mathrm{pH}$ and decreased as the $\mathrm{pH}$ increased. Cation exchange was the prevailing process at $\mathrm{pH}<5.0$; thus, $\mathrm{TC}$ adsorption decreased due to increasing total $\mathrm{Ca}^{2+}$ concentration. In contrast, Ca-bridging was the prevailing process at $\mathrm{pH}>5.0$; thus, $\mathrm{TC}$ adsorption increased with increasing $\mathrm{Ca}^{2+}$ concentration. Zhao et al. [47] investigated the adsorption of TC on kaolinite and found that $\mathrm{Ca}^{2+}$ and $\mathrm{Mg}^{2+}$ inhibited the adsorption of TC on kaolinite due to competition between $\mathrm{Ca}, \mathrm{Mg}$, and TC. Li et al. [48] investigated TC adsorption by activated sludge and found that TC competed with $\mathrm{Ca}^{2+}$ and $\mathrm{Mg}^{2+}$ ions at the adsorption sites in sludge.

\subsection{Adsorption Kinetics}

The adsorption kinetics and fitting curves of TC on HFO are shown in Figure 6. As the adsorption time increased, the amount of TC adsorbed by HFO initially increased and then tended to stabilize. Rapid adsorption of TC on HFO can be ascribed to adequate adsorption sites. The removal rate was greater than $90 \%$ within $200 \mathrm{~min}$.

The fitting parameters of adsorption kinetics are presented in Table 2 . It can be seen that compared with the pseudo-first-order kinetic model, the pseudo-second-order model better described the adsorption process and showed a higher correlation coefficient $(>0.99)$. Thus, chemical interactions played a major role in the adsorption process [49]. 




Figure 6. Adsorption kinetics of TC on HFO.

Table 2. Fitting parameters of adsorption kinetic.

\begin{tabular}{|c|c|c|c|c|c|}
\hline \multicolumn{3}{|c|}{ Pseudo-First Order Equation } & \multicolumn{3}{|c|}{ Pseudo-Second-Order Equation } \\
\hline$k_{1}\left(\min ^{-1}\right)$ & $q_{e}\left(\mathrm{mg} \cdot \mathrm{g}^{-1}\right)$ & $\mathbf{R}^{2}$ & $k_{2}\left(g \cdot(m g \cdot \min )^{-1}\right)$ & $q_{e}\left(m g \cdot g^{-1}\right)$ & $\mathbf{R}^{2}$ \\
\hline 0.06662 & 41.06197 & 0.96382 & 0.00214 & 42.3403 & 0.99479 \\
\hline
\end{tabular}

\subsection{Adsorption Isotherms}

The adsorption isotherm and fitting curve of TC on HFO are shown in Figure 7. The influence of temperature on the adsorption isotherm is also presented. With increased equilibrium concentration, the adsorption capacity increased and then tended to stabilize. Increased temperature was beneficial for the removal of TC by HFO. Increasing temperature can affect adsorption by changing the sorption capacity and also influencing the molecules diffusion rate, thus increasing or decreasing the time for adsorption equilibrium and then enhanced the adsorption of TC on HFO.

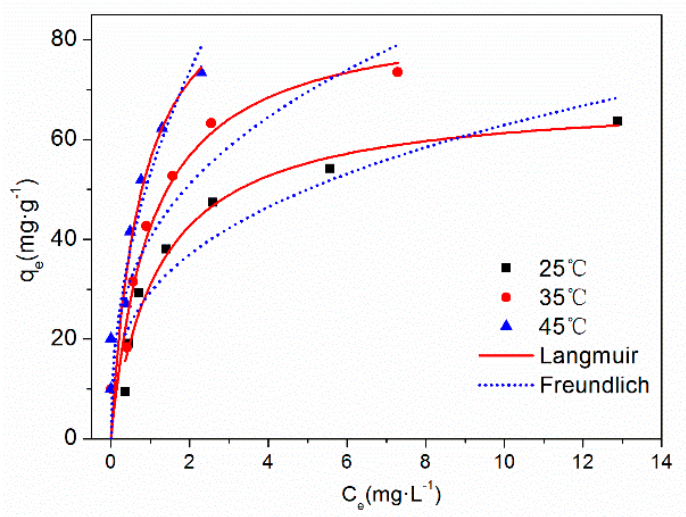

Figure 7. Adsorption isotherm of TC on HFO at different temperatures.

The fitting parameters of the adsorption isotherms are listed in Table 3. Compared with the Freundlich model, the Langmuir model fitted the adsorption isotherm process better. The maximum adsorption capacity of TC on HFO reached $99.49 \mathrm{mg} \cdot \mathrm{g}^{-1}$ at $318 \mathrm{~K}$. Compared with other iron oxide-based adsorbents [14,42,50-53], the maximum adsorption capacity of TC on HFO was high, indicating that HFO can effectively adsorb TC and further influence the behavior of TC in the aquatic environment. Adsorption proceeded easily when the $1 / \mathrm{n}$ was in the range of $0.1-0.5$ [54]. However, little adsorption occurred when $1 / \mathrm{n}$ was larger than 2 . In this study, the value of $1 / \mathrm{n}$ was less than 0.5 under the three temperatures, indicating that TC was easily adsorbed onto HFO. 
Table 3. Parameters of adsorption isotherm.

\begin{tabular}{|c|c|c|c|c|c|c|}
\hline \multirow{2}{*}{$\mathbf{T}(\mathbf{K})$} & \multicolumn{3}{|c|}{ Langmuir Model } & \multicolumn{3}{|c|}{ Freundlich Model } \\
\hline & $\mathrm{K}_{\mathrm{L}}\left(\mathrm{L} \cdot \mathrm{mg}^{-1}\right)$ & $\mathrm{q}_{\mathrm{m}}\left(\mathrm{mg} \cdot \mathrm{g}^{-1}\right)$ & $\mathbf{R}^{2}$ & $K_{F}\left(m g \cdot g^{-1}\right)\left(L \cdot \mu g^{-1}\right)^{1 / n}$ & $\mathbf{n}$ & $\mathbf{R}^{2}$ \\
\hline 298 & 0.82377 & 70.58543 & 0.97367 & 25.89622 & 0.3681 & 0.86966 \\
\hline 308 & 0.99445 & 87.58641 & 0.95776 & 41.95165 & 0.5040 & 0.93145 \\
\hline 318 & 1.29393 & 99.48959 & 0.94697 & 53.24752 & 0.4331 & 0.88921 \\
\hline
\end{tabular}

\subsection{Adsorption Thermodynamics}

A plot of $\ln \left(K_{d}\right)$ against $1 / T$ is shown in Figure 8. The thermodynamic fitting parameters of TC adsorption on HFO are listed in Table 4 . The $\Delta \mathrm{G}$ was $-8.7403,-10.1915$, and $-12.0669 \mathrm{~kJ} \mathrm{~mol}^{-1}$ at 298, 308, and $318 \mathrm{~K}$, respectively. Therefore, the adsorption process was spontaneous. When the temperature increased, spontaneous adsorption became stronger. The $\Delta \mathrm{H}>0$ indicated that the adsorption process was endothermic. $\Delta \mathrm{S}>0$ showed that the disorder of the adsorption system increased. $\Delta \mathrm{H}$ was $10.1431 \mathrm{~kJ} \mathrm{~mol}^{-1}$, which was less than $80 \mathrm{~kJ} \mathrm{~mol}^{-1}$ [55], indicating that physical binding also plays an important role during the adsorption process.

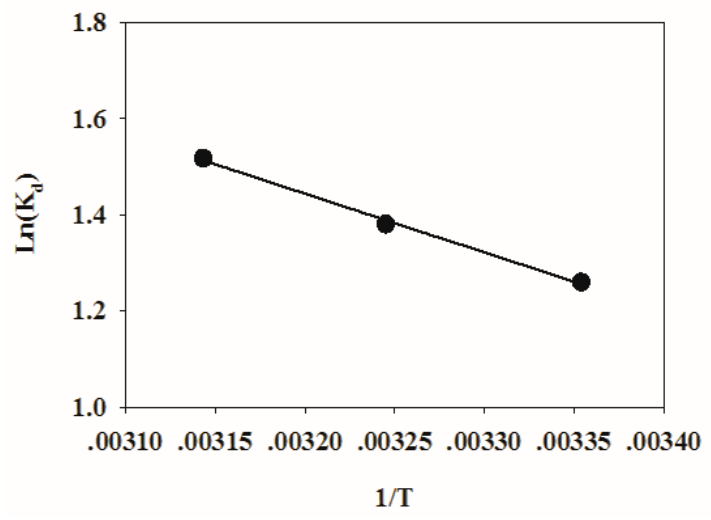

Figure 8. Plotting of $1 / \mathrm{T}$ to $\ln \left(\mathrm{K}_{\mathrm{d}}\right)$.

Table 4. Parameters of thermodynamic models for the adsorption of TC onto HFO.

\begin{tabular}{|c|c|c|c|}
\hline Temperature (K) & $\Delta \mathrm{G}\left(\mathrm{kJ} \mathrm{mol} \mathrm{mol}^{-1}\right)$ & $\Delta \mathrm{H}\left(\mathrm{kJ} \mathrm{mol} \mathrm{mol}^{-1}\right)$ & $\Delta S\left(\mathrm{~J} \mathrm{~mol}^{-1} \mathrm{~K}^{-1}\right)$ \\
\hline 298 & -8.7403 & & \\
\hline 308 & -10.1915 & 10.1431 & 44.4716 \\
\hline 318 & -12.0669 & & \\
\hline
\end{tabular}

\subsection{Adsorption Mechanism}

The mechanism between $\mathrm{HFO} /$ modified HFO and pollutant included surface complexation, ion exchange, and electrostatic interactions $[26,43,45,53,56]$. In this study, the adsorption mechanism of TC on HFO was examined by combining the influencing factors, adsorption kinetics, adsorption isotherm, and XPS and FTIR characterization of HFO after adsorption. The effect of $\mathrm{pH}$ indicated that electrostatic interactions affected the adsorption of TC on HFO. The removal rate of TC decreased slightly at $\mathrm{pH}<5.0$ and decreased significantly at $\mathrm{pH}>9.0$. The effect of ionic types and strengths showed that $\mathrm{K}^{+}$had little influence on TC removal, suggesting that the complexation between HFO and TC may be an inner-sphere complexation and not an outer-sphere complexation. The combination of TC and HFO was tight. The results of adsorption kinetics illustrated that chemisorption played a major role in the adsorption process.

According to the results of the adsorption isotherm, high temperature was beneficial for the adsorption process, and adsorption occurred spontaneously. The FTIR analysis showed that Fe-O and $-\mathrm{OH}$ were involved in the removal of $\mathrm{TC}$, which included electrostatic interactions and complexation. 
XPS analysis demonstrated that oxygen-containing groups participated in electrostatic interactions and complexation, nitrogen-containing groups were involved in electrostatic interactions and hydrogen bonding, and iron-containing groups were involved in complexation. Thus, the main mechanism of TC adsorption on HFO included electrostatic interactions, hydrogen bonding, and complexation.

\section{Conclusions}

The adsorption behavior of TC onto HFO could be affected by solution $\mathrm{pH}$, ionic types, and temperature. Pseudo-second-order adsorption kinetics and the Langmuir adsorption isotherm fitted the adsorption process well. Electrostatic interactions, hydrogen bonding, and complexation were the main adsorption mechanism between TC and HFO. Therefore, the environmental behavior of TC could be affected by HFO, and the transformation of TC affected by HFO in the aquatic environment should be studied in the future.

Author Contributions: Conceptualization, J.T. and S.F.; methodology, J.Z., T.W., H.S., and N.Z.; validation, Z.X., S.F., and J.T.; formal analysis, J.Z. and T.W., H.S., investigation, J.Z. and T.W., H.S.; resources, Z.X., S.F., and J.T.; data curation, J.T.; writing-original draft preparation, J.T.; writing-review and editing, Z.X., S.F.; visualization, J.T.; supervision, J.T.; project administration, J.T.; funding acquisition, Z.X., S.F., and J.T.

Funding: This study was financially supported by the National Natural Science Foundation of China (grant number 51609001, 51809001, and 51709002), the National Students' Innovation and Entrepreneurship Training Program (grant number 201810364206).

Conflicts of Interest: The authors declare no conflict of interest.

\section{References}

1. Zhang, Q.Q.; Ying, G.G.; Pan, C.G.; Liu, Y.S.; Zhao, J.L. Comprehensive evaluation of antibiotics emission and fate in the river basins of China: Source analysis, multimedia modeling, and linkage to bacterial resistance. Environ. Sci. Technol. 2015, 49, 6772-6782. [CrossRef] [PubMed]

2. Fu, Y.; Peng, L.; Zeng, Q.; Yang, Y.; Song, H.; Shao, J.; Shao, S.; Gu, J. High efficient removal of tetracycline from solution by degradation and flocculation with nanoscale zerovalent iron. Chem. Eng. J. 2015, 270, 631-640. [CrossRef]

3. Jing, X.R.; Wang, Y.Y.; Liu, W.J.; Wang, Y.K.; Jiang, H. Enhanced adsorption performance of tetracycline in aqueous solutions by methanol-modified biochar. Chem. Eng. J. 2014, 248, 168-174. [CrossRef]

4. Ahmadi, M.; Motlagh, H.R.; Jaafarzadeh, N.; Mostoufi, A.; Saeedi, R.; Barzegar, G.; Jorfi, S. Enhanced photocatalytic degradation of tetracycline and real pharmaceutical wastewater using MWCNT/TiO2 nano-composite. J. Environ. Manag. 2017, 186, 55-63. [CrossRef] [PubMed]

5. Mboula, V.M.; Héquet, V.; Gru, Y.; Colin, R.; Andrès, Y. Assessment of the efficiency of photocatalysis on tetracycline biodegradation. J. Hazard. Mater. 2012, 209-210, 355-364. [CrossRef]

6. Kümmerer, K. Antibiotics in the aquatic environment-A review-Part I. Chemosphere 2009, 75, 417-434. [CrossRef]

7. Gao, Y.; Li, Y.; Zhang, L.; Huang, H.; Hu, J.; Shah, S.M.; Su, X. Adsorption and removal of tetracycline antibiotics from aqueous solution by graphene oxide. J. Colloid Interface Sci. 2012, 368, 540-546. [CrossRef]

8. Zhu, W.; Wang, J.; Wang, Y.; Wang, H. Study on sulfadimethoxine removal from aqueous solutions by hydrous ferric oxides. Water Sci. Technol. 2016, 74, 1136-1142. [CrossRef]

9. Zhou, M.; Zhu, T.; Fei, X. Enhanced adsorption performance of oxytetracycline by desugared reed residues. Int. J. Environ. Res. Public Health 2018, 15, 2229. [CrossRef]

10. Li, J.; Pan, L.; Yu, G.; Xie, S.; Li, C.; Lai, D.; Li, Z.; You, F.; Wang, Y. The synthesis of heterogeneous Fenton-like catalyst using sewage sludge biochar and its application for ciprofloxacin degradation. Sci. Total Environ. 2019, 654, 1284-1292. [CrossRef]

11. Pan, L.; Cao, Y.; Zang, J.; Huang, Q.; Wang, L.; Zhang, Y.; Fan, S.; Tang, J.; Xie, Z. Preparation of iron-loaded granular activated carbon catalyst and its application in tetracycline antibiotic removal from aqueous solution. Int. J. Environ. Res. Public Health 2019, 16, 2270. [CrossRef] [PubMed]

12. Gómez-Pacheco, C.V.; Sánchez-Polo, M.; Rivera-Utrilla, J.; López-Peñalver, J. Tetracycline removal from waters by integrated technologies based on ozonation and biodegradation. Chem. Eng. J. 2011, 178, 115-121. [CrossRef] 
13. Liu, P.; Liu, W.J.; Jiang, H.; Chen, J.J.; Li, W.W.; Yu, H.Q. Modification of bio-char derived from fast pyrolysis of biomass and its application in removal of tetracycline from aqueous solution. Bioresour. Technol. 2012, 121, 235-240. [CrossRef] [PubMed]

14. Lin, Y.; Xu, S.; Li, J. Fast and highly efficient tetracyclines removal from environmental waters by graphene oxide functionalized magnetic particles. Chem. Eng. J. 2013, 225, 679-685. [CrossRef]

15. Oladoja, N.A.; Adelagun, R.O.A.; Ahmad, A.L.; Unuabonah, E.I.; Bello, H.A. Preparation of magnetic, macro-reticulated cross-linked chitosan for tetracycline removal from aquatic systems. Colloids Surf. B 2014, 117, 51-59. [CrossRef]

16. Yang, X.; Xu, G.; Yu, H.; Zhang, Z. Preparation of ferric-activated sludge-based adsorbent from biological sludge for tetracycline removal. Bioresour. Technol. 2016, 211, 566-573. [CrossRef]

17. Rivera-Utrilla, J.; Gómez-Pacheco, C.V.; Sánchez-Polo, M.; López-Peñalver, J.J.; Ocampo-Pérez, R. Tetracycline removal from water by adsorption/bioadsorption on activated carbons and sludge-derived adsorbents. J. Environ. Manag. 2013, 131, 16-24. [CrossRef]

18. Liu, J.; Zhu, R.; Xu, T.; Xu, Y.; Ge, F.; Xi, Y.; Zhu, J.; He, H. Co-adsorption of phosphate and zinc(II) on the surface of ferrihydrite. Chemosphere 2016, 144, 1148-1155. [CrossRef]

19. Liu, T.; Wang, H.; Zhang, Z.; Zhao, D. Application of synthetic iron-oxide coated zeolite for the pollution control of river sediments. Chemosphere 2017, 180, 160-168. [CrossRef]

20. Lu, J.; Liu, H.; Zhao, X.; Jefferson, W.; Cheng, F.; Qu, J. Phosphate removal from water using freshly formed Fe-Mn binary oxide: Adsorption behaviors and mechanisms. Colloids Surf. A 2014, 455, 11-18. [CrossRef]

21. Sujana, M.G.; Mishra, A.; Acharya, B.C. Hydrous ferric oxide doped alginate beads for fluoride removal: Adsorption kinetics and equilibrium studies. Appl. Surf. Sci. 2013, 270, 767-776. [CrossRef]

22. Zhang, H.; Elskens, M.; Chen, G.; Chou, L. Phosphate adsorption on hydrous ferric oxide (HFO) at different salinities and pHs. Chemosphere 2019, 225, 352-359. [CrossRef] [PubMed]

23. Nur, T.; Loganathan, P.; Nguyen, T.C.; Vigneswaran, S.; Singh, G.; Kandasamy, J. Batch and column adsorption and desorption of fluoride using hydrous ferric oxide: Solution chemistry and modeling. Chem. Eng. J. 2014, 247, 93-102. [CrossRef]

24. Yang, K.; Zhou, J.; Lou, Z.; Zhou, X.; Liu, Y.; Li, Y.; Ali Baig, S.; Xu, X. Removal of Sb(V) from aqueous solutions using Fe-Mn binary oxides: The influence of iron oxides forms and the role of manganese oxides. Chem. Eng. J. 2018, 354, 577-588. [CrossRef]

25. Mercer, K.L.; Tobiason, J.E. Removal of arsenic from high ionic strength solutions: Effects of ionic strength, $\mathrm{pH}$, and preformed versus in situ formed HFO. Environ. Sci. Technol. 2008, 42, 3797-3802. [CrossRef]

26. Gu, C.; Karthikeyan, K.G. Interaction of tetracycline with aluminum and iron hydrous oxides. Environ. Sci. Technol. 2005, 39, 2660-2667. [CrossRef]

27. Liu, W.J.; Zhu, Y.G.; Hu, Y.; Williams, P.N.; Gault, A.G.; Meharg, A.A.; Charnock, J.M.; Smith, F.A. Arsenic sequestration in iron plaque, its accumulation and speciation in mature rice plants (Oryza Sativa L.). Environ. Sci. Technol. 2006, 40, 5730-5736. [CrossRef]

28. Khan, N.; Seshadri, B.; Bolan, N.; Saint, C.P.; Kirkham, M.B.; Chowdhury, S.; Yamaguchi, N.; Lee, D.Y.; Li, G.; Kunhikrishnan, A.; et al. Chapter One-Root iron plaque on wetland plants as a dynamic pool of nutrients and contaminants. Adv. Agron. 2016, 138, 1-96.

29. Yan, D.; Ma, W.; Song, X.; Bao, Y. The effect of iron plaque on uptake and translocation of norfloxacin in rice seedlings grown in paddy soil. Environ. Sci. Pollut. Res. 2017, 24, 7544-7554. [CrossRef]

30. Lagergren, S.K. About the theory of so-called adsorption of soluble substances. Sven. Vetenskapsakad. Handingarl. 1898, 24, 1-39.

31. Blanchard, G.; Maunaye, M.; Martin, G. Removal of heavy metals from waters by means of natural zeolites. Water Res. 1984, 18, 1501-1507. [CrossRef]

32. Langmuir, I. The adsorption of gases on plane surfaces of glass, mica and platinum. J. Am. Chem. Soc. 1918, 40, 1361-1403. [CrossRef]

33. Freundlich, H. Über die adsorption in lösungen. Z. Phys. Chem. 1907, 57, 385-470. [CrossRef]

34. Khan, A.A.; Singh, R.P. Adsorption thermodynamics of carbofuran on $\mathrm{Sn}$ (IV) arsenosilicate in $\mathrm{H}^{+}, \mathrm{Na}^{+}$and $\mathrm{Ca}^{2+}$ forms. Colloids Surf. 1987, 24, 33-42. [CrossRef]

35. Fan, S.; Wang, Y.; Li, Y.; Tang, J.; Wang, Z.; Tang, J.; Li, X.; Hu, K. Facile synthesis of tea waste/Fe3O4 nanoparticle composite for hexavalent chromium removal from aqueous solution. RSC Adv. 2017, 7, 7576-7590. [CrossRef] 
36. Hofmann, A.; Pelletier, M.; Michot, L.; Stradner, A.; Schurtenberger, P.; Kretzschmar, R. Characterization of the pores in hydrous ferric oxide aggregates formed by freezing and thawing. J. Colloid Interface Sci. 2004, 271, 163-173. [CrossRef]

37. Mudunkotuwa, I.A.; Grassian, V.H. Biological and environmental media control oxide nanoparticle surface composition: The roles of biological components (proteins and amino acids), inorganic oxyanions and humic acid. Environ. Sci. Nano 2015, 2, 429-439. [CrossRef]

38. Qi, H.; Teng, M.; Liu, M.; Liu, S.; Li, J.; Yu, H.; Teng, C.; Huang, Z.; Liu, H.; Shao, Q.; et al. Biomass-derived nitrogen-doped carbon quantum dots: Highly selective fluorescent probe for detecting $\mathrm{Fe}^{3+}$ ions and tetracyclines. J. Colloid Interface Sci. 2019, 539, 332-341. [CrossRef]

39. Okazaki, M.; Sakaidani, K.; Saigusa, T.; Sakaida, N. Ligand exchange of oxyanions on synthetic hydrated oxides of iron and aluminum. Soil Sci. Plant Nutr. 1989, 35, 337-346. [CrossRef]

40. Kosmulski, M. Compilation of PZC and IEP of sparingly soluble metal oxides and hydroxides from literature. Adv. Colloid Interface Sci. 2009, 152, 14-25. [CrossRef]

41. Zhang, P.; Li, Y.; Cao, Y.; Han, L. Characteristics of tetracycline adsorption by cow manure biochar prepared at different pyrolysis temperatures. Bioresour. Technol. 2019, 285, 121348. [CrossRef] [PubMed]

42. Wu, H.; Xie, H.; He, G.; Guan, Y.; Zhang, Y. Effects of the $\mathrm{pH}$ and anions on the adsorption of tetracycline on iron-montmorillonite. Appl. Clay Sci. 2016, 119, 161-169. [CrossRef]

43. Zhao, Y.; Gu, X.; Gao, S.; Geng, J.; Wang, X. Adsorption of tetracycline (TC) onto montmorillonite: Cations and humic acid effects. Geoderma 2012, 183-184, 12-18. [CrossRef]

44. Yang, W.; Zheng, F.; Lu, Y.; Xue, X.; Li, N. Adsorption interaction of tetracyclines with porous synthetic resins. Ind. Eng. Chem. Res. 2011, 50, 13892-13898. [CrossRef]

45. Ji, L.; Chen, W.; Duan, L.; Zhu, D. Mechanisms for strong adsorption of tetracycline to carbon nanotubes: A comparative study using activated carbon and graphite as adsorbents. Environ. Sci. Technol. 2009, 43, 2322-2327. [CrossRef]

46. Parolo, M.E.; Avena, M.J.; Pettinari, G.R.; Baschini, M.T. Influence of $\mathrm{Ca}^{2+}$ on tetracycline adsorption on montmorillonite. J. Colloid Interface Sci. 2012, 368, 420-426. [CrossRef]

47. Zhao, Y.; Gu, X.; Li, S.; Han, R.; Wang, G. Insights into tetracycline adsorption onto kaolinite and montmorillonite: Experiments and modeling. Environ. Sci. Pollut. Res. 2015, 22, 17031-17040. [CrossRef]

48. Li, B.; Zhang, T. Removal mechanisms and kinetics of trace tetracycline by two types of activated sludge treating freshwater sewage and saline sewage. Environ. Sci. Pollut. Res. 2013, 20, 3024-3033. [CrossRef]

49. Ho, Y.S.; McKay, G. Pseudo-second order model for sorption processes. Process. Biochem. 1999, 34, 451-465. [CrossRef]

50. Peng, L.; Ren, Y.; Gu, J.; Qin, P.; Zeng, Q.; Shao, J.; Lei, M.; Chai, L. Iron improving bio-char derived from microalgae on removal of tetracycline from aqueous system. Environ. Sci. Pollut. Res. 2014, 21, 7631-7640. [CrossRef]

51. Zhang, Z.; Lan, H.; Liu, H.; Li, H.; Qu, J. Iron-incorporated mesoporous silica for enhanced adsorption of tetracycline in aqueous solution. RSC Adv. 2015, 5, 42407-42413. [CrossRef]

52. Zhou, Y.; Liu, X.; Xiang, Y.; Wang, P.; Zhang, J.; Zhang, F.; Wei, J.; Luo, L.; Lei, M.; Tang, L. Modification of biochar derived from sawdust and its application in removal of tetracycline and copper from aqueous solution: Adsorption mechanism and modelling. Bioresour. Technol. 2017, 245, 266-273. [CrossRef] [PubMed]

53. Tanis, E.; Hanna, K.; Emmanuel, E. Experimental and modeling studies of sorption of tetracycline onto iron oxides-coated quartz. Colloids Surf. A 2008, 327, 57-63. [CrossRef]

54. Tang, H.; Huang, H.; Wang, X.; Wu, K.; Tang, G.; Li, C. Hydrothermal synthesis of 3D hierarchical flower-like $\mathrm{MoSe}_{2}$ microspheres and their adsorption performances for methyl orange. Appl. Surf. Sci. 2016, 379, 296-303. [CrossRef]

55. Chowdhury, S.; Mishra, R.; Saha, P.; Kushwaha, P. Adsorption thermodynamics, kinetics and isosteric heat of adsorption of malachite green onto chemically modified rice husk. Desalination 2011, 265, 159-168. [CrossRef]

56. Zhang, Z.; Liu, H.; Wu, L.; Lan, H.; Qu, J. Preparation of amino-Fe (III) functionalized mesoporous silica for synergistic adsorption of tetracycline and copper. Chemosphere 2015, 138, 625-632. [CrossRef]

(C) 2019 by the authors. Licensee MDPI, Basel, Switzerland. This article is an open access article distributed under the terms and conditions of the Creative Commons Attribution (CC BY) license (http://creativecommons.org/licenses/by/4.0/). 